\title{
REAL ESTATE STRATEGIC MANAGEMENT MODEL FOR LITHUANIAN MUNICIPALITIES
}

\author{
Egle KLUMBYTE ${ }^{\text {a,*, Rasa APANAVICIENE }}$ a \\ ${ }^{a}$ Faculty of Civil Engineering and Architecture, Kaunas University of Technology, Studentu g. 48, \\ LT-51367 Kaunas, Lithuania
}

Received 8 January 2013; accepted 14 June 2013

\begin{abstract}
Within the municipal boundaries, municipalities themselves are usually the largest real estate owners and managers. Such significant amount of real estate property could be expected to be professionally managed; however, the situation is different. According to the latest publications, only about $25 \%$ of major European cities are able to follow the quantity and value of their real estate portfolios. The Lithuanian Free Market Institute has recently introduced its first Index of Municipalities in Lithuania and states that none of the Lithuanian municipalities has developed its real estate management strategy. This paper reviews the scientific research on municipal real estate management and analyses the system of real estate management in Lithuanian municipalities. The authors of the paper collaborated with the Association of Local Authorities in Lithuania as well as the representatives of municipalities, and together they identified the main problems of real estate management. On the basis of real estate management research and practice within Lithuanian municipalities the authors of the paper present a brand new model which would help to manage municipal real estate effectively by taking into account the priorities of strategic economic and social development tendencies of the region.
\end{abstract}

KEYWORDS: Real estate; Strategic management; Management model; Municipality

\section{INTRODUCTION}

In many countries, municipalities are not only the owners, but also the managers of real estate (hereinafter referred to as "RE"). They control a large amount of $\mathrm{RE}$, including public buildings, infrastructure objects, schools, health care institutions, social housing and the surrounding land. They also own estate necessary for carrying out their administrative functions. It requires maintenance, foreseeing long-term objectives for its use and investment perspectives. Municipal portfolios need to be optimised through their management to ensure that they meet public interest (Kaganova, Nayyar-Stone 2000).

Having re-established the independent state in 1990, on the basis of the Law on Local SelfGovernment, City and District Councils were established, and later City and District Boards were elected as well. After the Law on Administrative Units and their Borders of the Republic of Lithuania had been adapted in 1994, 12 City and 44

\footnotetext{
* Corresponding author. E-mail: egle.klumbyte@ktu.lt
}

District Municipalities were established (while previous Parish and Village Municipalities were abolished). Moreover, following the current Law on Administrative Units and their Borders of the Republic of Lithuania, 60 municipalities, i.e. 60 state administrative units, were established, each of them being entitled with a legal entity status and the right for self-government, implemented through Self-Government Council and guaranteed by the Constitution of the Republic of Lithuania. The municipalities as such are subordinate to the Ministry of the Interior and the Government. Now, according the data of the Lithuanian Statistics Department of January 2013, the number of residents in the city and district municipalities of Lithuania ranges from 537152 residents in the largest Vilnius City Municipality to 2719 in the smallest Neringa City Municipality.

After regaining the independence Lithuania and its municipalities took over not only a considerable amount of RE, but also many shortfalls in its management. The lack of knowledge, experience and strategies has so far been the character- 
istic trait of $\mathrm{RE}$ management in the public sector. Municipal or state institutions are often assigned functions on the basis of the owned RE, although this should be the opposite case: the need for RE should be determined by the functions of the municipality/state. This may be the reason why currently none of the Lithuanian municipalities has a RE management strategy defining long-term plans for managing the owned property. The majority of Lithuanian municipalities had only approved Real Estate Management Procedures (Zukauskas 2011).

Presently, only about $25 \%$ of major European cities are able to provide data on the amount and value of their public RE (Deloitte Real Estate Advisory 2011); however, the situation is expected to change soon. RE managers have already acknowledged the benefit of professional RE management as it enables not only to reduce the costs, but also helps to solve social and developmental issues as well as those concerning expansion of the cities (Halfawy 2008).

One of the most relevant objectives to ensure more effective RE management in the municipalities is the improvement of the quality of provided services. This may be done by applying modern principles of real estate management for administrating the property of the municipality, i.e. for its purchase, lease, maintenance and renovation.

This paper aims to overview the research on municipal RE, analyse RE management system in Lithuania and, finally, present a newly developed $\mathrm{RE}$ strategic management model for municipalities.

\section{LITERATURE REVIEW}

Municipal RE management is an important object of scientific and practical research in different countries all over the world. In addition to scientific research, professional and practitioner asso- ciations' activities also have significant impact in this area. Relevant researches on RE management often appear in publications and recommendations of financial institutions, audit companies, (e. g., World Bank, Deloitte, etc.), international institutes and good practice centres. Scientists of different countries are also working in municipal real estate management. On the basis of the analysis of published scientific researches, five different focus areas have been identified (Table 1).

The research carried out in the scope of the first group comprises the principles and objectives of territorial planning which are similar in different countries. Such principles and objectives are targeted towards balancing territorial development, creating real-value environment for residents, making policies on residential areas and infrastructure system development, consuming natural resources sustainably, establishing preconditions for re-creation and preservation of eco-balanced landscaping, arranging lands, determining the purpose of future territories promoting investment into socio-economic development.

However, the process of territorial planning is complicated and, thus causes some negative consequences, such as considerable cost of time and resources required for the preparation of territorial planning documents, lack of institutions providing services on territorial planning (consultations and assistance), rather poor informational database, priority given to administrative territorial planning rather than realistic urban systems, unfinished process of ownership restitution, assessment of cadastral plans on the basis of territorial planning documents failing to ensure the effectiveness of territorial planning system. In the last decade, active efforts were put into the development of municipal RE management and research was carried out aiming to determine the areas where RE development is vital (Halfawy 2010).

Table 1. Main directions of scientific research on municipal RE

\begin{tabular}{|c|c|c|}
\hline No. & Research focus areas & Authors \\
\hline 1. & $\begin{array}{l}\text { Principles of territorial planning and } \\
\text { their influence on RE development }\end{array}$ & $\begin{array}{l}\text { Kaganova et al. (2008), Boamah et al. (2012), Halfawy (2010), Jacobs } \\
\text { (2012), Peti (2012). }\end{array}$ \\
\hline 2. & $\begin{array}{l}\text { Management of environmental pro- } \\
\text { tection objects }\end{array}$ & $\begin{array}{l}\text { Yard (2004), Vidanaarachchi et al. (2006), Zotos et al. (2009), Abrate et al. } \\
\text { (2011), Okot-Okumu and Nyenje (2011), Anghinolfi et al. (2013). }\end{array}$ \\
\hline 3. & $\begin{array}{l}\text { Management and development of } \\
\text { engineering infrastructure objects }\end{array}$ & Wang and Sinha (2004), Lumbers et al. (2010), Halfawy 2010. \\
\hline 4. & $\begin{array}{l}\text { Application of information technology } \\
\text { tools for real estate management }\end{array}$ & $\begin{array}{l}\text { Pijanowski et al. (2002), Venigalla and Baik (2007), Zavadskas et al. } \\
\text { (2010). }\end{array}$ \\
\hline 5. & $\begin{array}{l}\text { Analysis and evaluation methods of } \\
\text { RE management effectiveness }\end{array}$ & $\begin{array}{l}\text { Ghapanchi et al. (2012), Huang and Wang (2005), Kaganova et al. (2008), } \\
\text { Phelps (2011), Sun et al. (2008). }\end{array}$ \\
\hline
\end{tabular}


As sustainable development has become one of the main and most popular developmental concepts as well as the basis in the European development policy, Peti (2012) determined that applying sustainable development to territorial planning may increase the value of the asset. Jacobs (2012) analysed the process of planning in different countries and concluded that city planning is influenced by individual property rights. Author presents the example of Germany where territorial planning functions are the basis for reasonable use of land and great deal of attention is given to the promotion of economic development in the society, diminishing of economic differences among different regions, protecting and using natural resources sustainably. Research on the Ghanaian municipal construction development control by Boamah et al. (2012) revealed the absence of municipal development control, limited information of society on the foreseen territorial planning. Boamah et al. (2012) also states that in order to ensure the wellbeing of the residents, strict land use control in the municipalities is crucial.

Kaganova et al. (2008) emphasized the public principles while preparing strategic plans for land management. By applying better management practice during the preparation of strategic plans for land management in five cities of post-Soviet Kyrgyzstan, it has been achieved that the land was registered in the public registers, the results were publicly announced and a strategic management plan according to the main public RE management principles has been developed without the interference of corruption processes.

The research in the second group shows the peculiarities and shortfalls of the management and administration of environmental RE objects, such as waste plants and landfills. Abrate et al. (2011) carried out a research on the expenses required for waste collection and treatment in the Italian municipalities by applying the constituent price function model. The results demonstrated that joint management would be the most efficient decision to save up to $20 \%$ of expenses. Anghinolfi et al. (2013) proposed GIS-integrated decision making model for waste collection and management. During the implementation of the research, the model was applied to the Italian municipalities. The results demonstrated that the application of the proposed model resulted in 2.5 times better effect than the waste collection policy currently used in effect.

Zotos et al. (2009) stated that the implementation of the environmental policy is insufficient on the municipal level in Greece. Since the data are neither collected, nor followed or analysed, the integrated environment management policy is not implemented. The principal causes of the shortfalls in waste management are insufficient budget for its implementation and ignorance of the proposed strategies. Taking into account the causes of ineffective management, Zotos et al. (2009) proposed different schemes for cooperation between local authorities and service suppliers.

In Uganda landfill management is organized by decentralization policy in order to achieve sustainable waste management. However, City Councils fail to follow the waste management requirements for landfill administration. Such situation in solid waste management is observed because of national environmental strategy and poor mobilization resources. In comparison to other areas, less than $10 \%$ of City Council Budget is allocated to waste management. Thus, having analysed the nature and properties of the generated waste, organization of its collection and disposal, Okot-Okumu and Nyenje (2011) determined the interested parties participating in waste management as well as their responsibilities; on the basis of the processed data, the author suggested a solid waste treatment model.

Similarly, research carried out by Vidanaarachchi et al. (2006) showed that in Sri Lanka only $24 \%$ of households are provided with the infrastructure to deliver waste to municipal economy, whereas in rural areas this possibility is accessible to as few as $2 \%$ of residents. Yard (2004) overviewed the rates of waste management and aspects of pricing in Sweden; his proposals focus on the idea that the mark up to the price of a public service, added by a municipality, cannot exceed the determined costs of that service.

The research in the scope of the third group involves the processes and development of municipal infrastructure management. Infrastructure object management is a complicated process encompassing continual data collection, compilation, processing and further use. Halfawy (2010) carried out a research on the municipal data compilation models which revealed that the process of making decisions on infrastructure management should be integrated into the data and software systems that are usually used by different municipal divisions. The lack of task distribution in data collection and work processes causes serious problems that complicate effective management decisions. Halfawy (2010) suggested eliminating differences among distinctive functional groups by applying 
effective data integration, ensuring data sharing among divisions and in this way optimizing their management.

Lumbers et al. (2010) presented an integrated asset management planning system, known as "Pioneer". This system, used in Great Britain, encompasses the whole RE on the ground and under the ground. It is an advanced array of models enabling the user to forecast client service measures, cost and optimal amount of investment necessary for achieving the goals set for the services provided for infrastructure objects. In addition, Wang and Sinha (2004) proposed a GIS data-based information system for managing municipal engineering networks. It would facilitate the maintenance and management of engineering networks (water, sewage, electricity, gas and roads), determination of the need to repair the existing and to build the new networks, as well as enable reducing the costs for the technical assessment and repair of the existing ones.

Regardless of the developed infrastructure object management systems, municipalities still face increasing difficulties caused by depreciation of some RE, i.e. deterioration of its technical condition. Moreover, insufficient funding for engineering network renovation, growing demand and tightened requirements for service quality improvement and environmental protection are persistent issues that arise in urban municipalities (Halfawy 2010).

The research in the fourth group analyses the advantages and shortfalls of applying software and IT tools for municipal RE management in the public sector. Having carried out a research in Vilnius Municipality, Zavadskas et al. (2010) determined a number of causes of the limited use of IT in Lithuanian municipalities, health care and educational institutions. The causes include the high level of shadow economy, low level personnel competence, migration of IT specialists to foreign countries, etc. Apart from the mentioned, the European Union funds allocated for IT projects is not used effectively. On the other hand, the work of the Lithuanian municipalities is simplified due to the electronic signature and electronic public procurement system (Zavadskas et al. 2010).

Pijanowski (2002) proposed a model combining geo-information systems (GIS) and artificial neural networks. The model enables forecasting changes in land use and possible population density in the region on the basis of the following factors: road location, location of streets and motorways, distance to rivers and lakes, level of agriculture, landscape, etc. After carrying out the research, the conclusion was made that GIS may be applied as a useful tool for solving data modelling issues related to different complex tasks. If several complicated engineering management functions are connected, GIS platform may be used to automate them. Then the system solves the task automatically, which further enhances the productivity (Venigalla, Baik 2007). The GIS system currently installed in municipalities facilitates the management of general administration services, such as collection of revenues, review of archival data and information dissemination.

Research of Kaganova (2012) demonstrated that after installation GIS system and registration of 12,500 new objects in Karlovac city, municipalities using GIS platform as a part of RE management model has started to solve previously unresolved $\mathrm{RE}$ management issues related to $\mathrm{RE}$ registration.

Finally, the research carried out in the scope of the fifth group analyses the factors impacting the effectiveness of RE management and methods of effectiveness evaluation. Collaborating with the Urban Institute, Kaganova et al. (2008) determined that realization of strategic plans requires better management practice and improved strategy, emphasizing the principles of activity and plans of implementation.

Scientists have also analysed mathematical methods and intelligent systems that might be applied for the assessment of RE management efficiency. The research in this field is most widely developed in the Scandinavian countries; a substantial number of recent publications in the field show that estimation of RE management efficiency is a relevant topic nowadays. Accordingly, effective $\mathrm{RE}$ project assessment systems were determined to have a direct impact on the productivity and profitability of an organization as they help to save taxpayers' money and increase labour productivity. Various methods of analysis were proposed for determining RE management effectiveness, starting from weighted points to complicated mathematical programming methods.

Ghapanchi et al. (2012) explained that assessment of the possible risk is essential in $\mathrm{RE}$ management process. Huang and Wang (2005) developed an advance warning system forecasting changes in municipal RE market while taking into account variable effect of policy regulation that was applied in Shezen city. The system facilitates the assessment of changes in RE management and efficiency. Similarly, Sun et al. (2008) proposed an unbounded set theory for risk assessment of $\mathrm{RE}$ 
projects by employing linguistic and fuzzy variables. The main advantage of this method is that it enables the specialists and engineers to express their opinions on the variables of project risk assessment.

Phelps (2011) proposed an analytical framework and adapted it to the municipalities' research in the UK and Russia. Despite the fact that the Russian asset management is advanced less than in the UK, both countries studies revealed the same critical success factors: concentrated strategy, the will of organization, intelligent portfolio formation and entrepreneurial culture, which leads to efficient asset management. By employing these factors, existing practice and analysis of the research results, the author suggested a typology, which was used as a simple metrics system that allows classifying organizations in accordance to their maturity and asset management development.

The overview of the problem spheres analysed by the scientists revealed that different development level of countries results in different scientific priorities applied to solving RE management problems in different countries. Considering the situation of Lithuanian municipalities, the most problematic is the fifth systematic group, which detailed analysis is given in the following Section of the paper.

\section{THE ANALYSIS OF REAL ESTATE MANAGEMENT IN LITHUANIAN MUNICIPALITIES}

The activity of municipalities is relevant for both the citizens and investors. The areas of concern of the former, such as education, social and health care, public sector, transport, are governed by the local government, i.e. municipalities, rather than the central. Municipalities also develop the investment setting, business conditions and establish tax rates which are important to the corporate sector. All municipal property must serve as the means for achieving the most important purpose that is, ensuring economic freedom and wellbeing of people through the provided services. The activity of municipalities determines the efficiency of property management, use of taxpayers' money and bureaucratic burden placed on the citizens (Lithuanian Free Market Institute and Lithuanian Real Estate Development Association 2008).

The management system of public RE in municipalities of the Republic of Lithuania was analysed considering the problems related to strate- gic management of $\mathrm{RE}$, which were discussed in the scientific researches, and collaborating with the Association of Local Authorities in Lithuania and the representatives of municipalities. According to Deloitte Real Estate Advisory (2011) effective $\mathrm{RE}$ management requires a functioning public $\mathrm{RE}$ management system composed of the organization, strategy, information data system, financing and $\mathrm{RE}$ portfolio.

\subsection{RE portfolio}

Municipalities provide a great deal of services which require $\mathrm{RE}$; thus, they own a very wide $\mathrm{RE}$ portfolio and its management is especially difficult due to the variety in the purpose of the property use, differences in the requirements for its maintenance and needs of its users. Governments own property and infrastructure for performing their functions and for many other reasons (Kaganova 2010).

As the owners of RE, the municipalities face problems related to the strategic $\mathrm{RE}$ portfolio management, investment into $\mathrm{RE}$, its lease and maintenance, bearing of financial risk, sale of unnecessary property, construction or purchase of the necessary buildings. In Lithuania, the process of $\mathrm{RE}$ management is carried out in accordance with the governing normative and legal basis: the Law on the Possession, Use and Disposal of State and Municipal Property, Local Government Law, Civil Code, Law on Land and Law on the Privatization of State-Owned and Municipal Property.

The Centralized State Property Management Strategy for 2009-2016 claims that "in Lithuania, a part of state-owned property is neither assessed, nor registered in public registers, not all property has been included into property manager accounts and presented in financial reports. Therefore, the report on the property owned by the municipality under the right of ownership does not demonstrate the actual, well-grounded financial state of the municipal property" (Government of the Republic of Lithuania 2009). Municipal property managers of the Republic of Lithuania make unsatisfactory decisions on the further use of the unnecessary property not employed for realizing municipal functions, because an institution responsible for collecting and summarizing the data on the unused property has not been established.

$\mathrm{RE}$ of Lithuanian municipalities is classified into the three main groups: residential, non-residential and engineering buildings. The authors of the paper suggest forming RE management portfo- 
lios by allocating municipal $\mathrm{RE}$ to the services provided by the municipalities according to the Technical Construction Regulation, STR 1.01.09:2003 "Classification of Buildings According to the Purpose of Their Use" (Ministry of Environment of the Republic of Lithuania 2003) (Fig. 1).

\begin{tabular}{|l|}
\hline SERVICES \\
\hline Health care services \\
\end{tabular}

Social care services

\begin{tabular}{|l|}
\hline Social care services \\
\hline Basic/ compulsory educa- \\
tion; pre-school, after- \\
school, special education \\
services
\end{tabular}

Passenger and load transportation services

Public transport services

-

Central heating, water, gas, electricity supply, household sewage collection and cleaning services

\begin{tabular}{|l|}
\hline $\begin{array}{l}\text { Public waste collection } \\
\text { services }\end{array}$ \\
\hline
\end{tabular}

Non-commercial, leisure services

Tourism services

Cemeteries and cultural heritage, monuments

Other

Fig. 1. Services provided by municipalities and required RE

\subsection{Organization}

As has been mentioned, municipal $\mathrm{RE}$ is great in its amount and wide in the scope of usage. The majority of municipal property was built in the central parts of towns in the first half of the $20^{\text {th }}$ century or even earlier; it is morally and functionally outdated, its book value is usually low, while energy and maintenance costs are high. Municipalities supervise the maintenance and use of the property, coordinate the activity of companies managing the building sector, solve issues related to the use of the available resources, and prepare strategic development plans and ordinances on the issues of the property use. Currently two main different systems for the organization of building exploitation and economy management prevail worldwide, and the same principles apply to Lithuania. The first system is when the owner takes care of the building exploitation by arranging the activities of $\mathrm{RE}$ management, whereas the second one is when the owner has no possibilities to execute exploitation or repair, thus, assigns this work to relevant organizations (Lepkova, Vilutiene 2008). The main objective of the municipalities is to reduce the $\mathrm{RE}$ operation and management costs. However, the focus must be directed towards long-term $\mathrm{RE}$ management objectives from the future perspective, rather than short-term ones aimed only at the reduction of costs regarding the available property as a possession (Phelps 2010). To achieve this, the functions related to RE management were defined and their execution was ascribed to the municipal departments and divisions implementing the aims provided in the strategy. Some of the divisions carry out only a single function, whereas the others were assigned several of them (Fig. 2).

Issues related to the exploitation of municipal buildings and infrastructure is solved with help of special municipal companies and service departments: facility management companies and their activity are a part of the whole $\mathrm{RE}$ maintenance and operation sector of the municipality. Municipal sector encompasses different companies and organizations that supervise the municipality. Apart from the companies supervising building and infrastructure sector, the structure of the service companies includes other $\mathrm{RE}$ sectors owned by the municipality, while the system of public building and infrastructure sector is composed of specific company and service groups (Fig. 3).

Since the operation of municipal RE is run by municipal companies that usually lack financing, the EU Commission is currently working on the 


\begin{tabular}{|c|c|c|}
\hline FUNCTIONS & & DIVISIONS \\
\hline $\begin{array}{l}\text { Planning, set-up of } \\
\text { programmes and } \\
\text { priorities }\end{array}$ & $\rightarrow$ & $\begin{array}{l}\text { Strategic Planning and Investment Division, RE } \\
\text { Division }\end{array}$ \\
\hline Formation of RE budget & $\rightarrow$ & $\begin{array}{l}\text { Assets Division, Strategic Planning and Investment } \\
\text { Division }\end{array}$ \\
\hline Accounting & $\rightarrow$ & $\begin{array}{l}\text { Assets Division holds the responsibility for data } \\
\text { presentation and distribution; Economy Division } \\
\text { for submission of reports }\end{array}$ \\
\hline $\begin{array}{l}\text { Application of informa- } \\
\text { tion systems }\end{array}$ & $\rightarrow$ & Information Technologies Division \\
\hline Data collection & $\rightarrow$ & Assets Division, Information Technologies Division \\
\hline $\begin{array}{l}\text { Compilation of finan- } \\
\text { cial reports }\end{array}$ & $\rightarrow$ & Economy Division \\
\hline $\begin{array}{l}\text { Preparation of invest- } \\
\text { ment programmes/ } \\
\text { projects }\end{array}$ & $\rightarrow$ & $\begin{array}{l}\text { Project Preparation Group accountable to the } \\
\text { Director of Municipality Administration }\end{array}$ \\
\hline Audit & $\rightarrow$ & Internal Audit Service of the Municipality \\
\hline Territory planning & $\rightarrow$ & Territory Planning Division \\
\hline $\begin{array}{l}\text { Public procurement } \\
\text { services }\end{array}$ & $\rightarrow$ & $\begin{array}{l}\text { Assets Management and Public Procurement } \\
\text { Division }\end{array}$ \\
\hline
\end{tabular}

Fig 2. RE management functions on the municipal level

Concession Directive. Following the EU Commission, the Directive would facilitate the shift of private companies into the public sector, which would stimulate the partnership of both sectors. Consequently, the provision of services by private companies would enable more effective public estate management.

\subsection{IT system}

In the $21^{\text {st }}$ century, information systems play an important role in the lives of people. State Inspection Reports regularly indicate the following problems, encompassing all types of municipal property management in Lithuania, that have become systemic: a part of municipal property is not assessed and registered in public registers, municipal $\mathrm{RE}$ management is decentralised, no exact data on the amount of municipal property and its management are available, there is no common and effective state RE management inspection system. In the process of $\mathrm{RE}$ management, appropriate communication and linking of the available information are of primary importance, because the municipalities have to be aware not only of the type of the owned property, but also its state, the necessary investments, need for the property, etc. Kaganova (2012) research revealed that creation of an accurate database and inventory of municipal assets is the first important step towards effective asset management system creation. A comprehensive database allows municipalities to analyse and monitor their RE assets and portfolios, as well as to develop and implement the strategic plan for managing various types of municipal $R E$.

For example: The UK Office of Government Commerce (OGC) ensures the efficiency of municipal property management as it is responsible for its promotion, implements the programmes for more efficient management and use of property, including transfer and consolidation of $\mathrm{RE}$ owned by the state institutions. OGC also administers the RE database (The Electronic Property Information Mapping Service; e-PIMS) to which centrally controlled institutions submit information

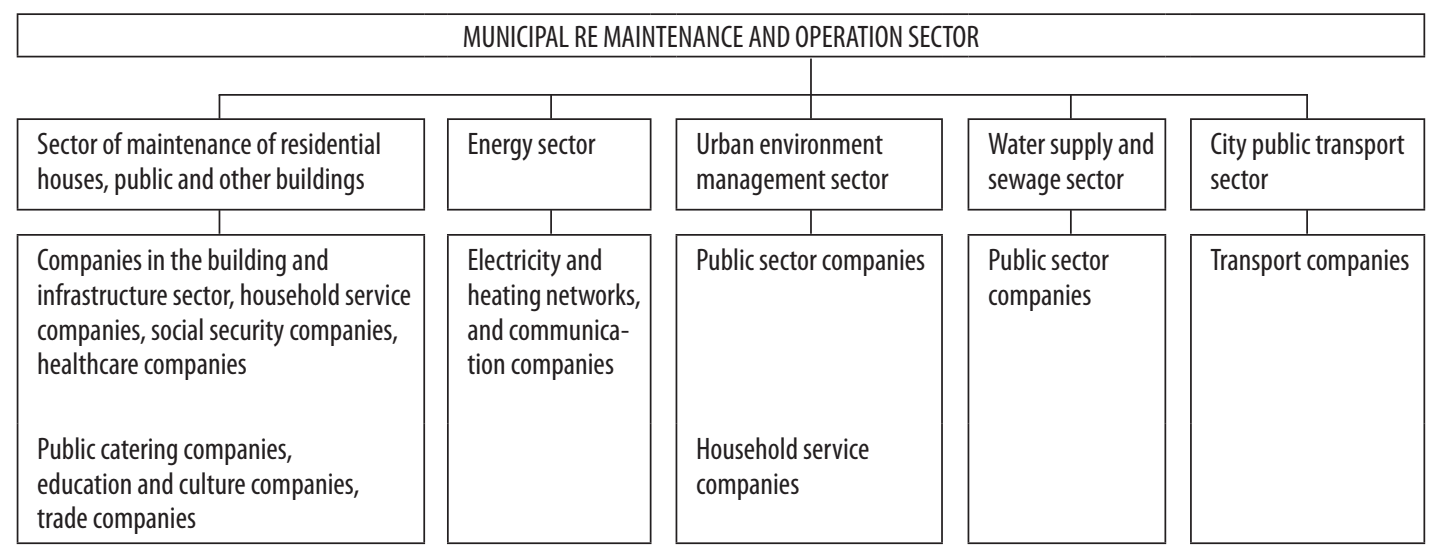

Fig. 3. Organization of municipal RE maintenance and operation activity (with reference to Lepkova, Vilutiene 2008) 
about their property on compulsory basis. E-PIMS enables accessing and sharing $\mathrm{RE}$ maps and information about the whole property owned by the central government, search for information in different sections, and search for available property necessary for governmental institutions. Moreover, the Property Benchmarking Service, a tool of the database for research of property management efficiency installed by OGC, allows comparing $\mathrm{RE}$ management efficiency of different institutions (National Audit Office 2004). However since it is not mandatory for UK councils to add data to ePIMMS (rather it is encouraged) up to date the degree to which councils have willingness to do this is disappointing.

Back in 2007, the Lithuanian public company State Property Fund was assigned to implement the development of the State Property Search Engine, which would store the information on the available state property. The preparation of the necessary legislation and its approval took two years. Thus, under the Decision No. 813 on the Introduction and Approval of Regulations for State Property Search Engine, made on 22 July 2009 by the Government of the Republic of Lithuania, a State Property Search Engine was established and its regulations were approved. Moreover, its administration was appointed to the Ministry of Finance, while management to the State Property Fund. However, the system has not been launched yet and provides no actual results as originally intended, i.e. to hold the information on the available property in one place and to analyse it in different cross-sections, which would provide for better public property management and at least partially solve the issues of $\mathrm{RE}$ registration and valuation.

For the first time in 22 years of independence, Vilnius City Municipality presented information about the value of its RE: the announcement of Mayor, made in May 2012, states that the market value of the total municipal property amounts to about 9 billion LTL. Other cities are also expected to follow the example of the capital and submit the data about the amount, size and value of the owned property. To save municipal budget finances allocated for the RE management and to concertedly solve systemic problems in the state property management, the development of $\mathrm{RE}$ information system for collecting, processing and analysing information on the property owned by municipalities under the right of ownership is vital. It would create conditions for using the collected information on municipal property for making more rational management solutions. Such system has not been developed yet, thus, detailed information about state-owned property is not available. The installed information system would enable collecting information on municipal property and provide conditions for centralised solution of systemic property management issues, rational decisions of municipal property managers on municipal $\mathrm{RE}$ management, analyse municipal RE management efficiency, implement centralised state RE inspection system and principles of management. The development of such system must be based on strategic aims of the municipalities and integrated into the main management strategy (Deloitte Real Estate Advisory 2011).

\subsection{Financing}

The income to municipal budgets is generated from the following sources: taxes received to municipal budgets under the laws and other legislation; income from municipal property; fines paid under the order determinated by laws; local levies; income of municipal budgetary institutions for the provided services; income from the financial balance in the running accounts of the municipalities; income received under the order determinate by the Government after distributing the revenue for the sold and leased state-owned non-agricultural land; state budget subsidies and other transferred finances; other income under the laws of the Republic of Lithuania; unpaid financial support (Association of Local Authorities in Lithuania 2012). On the basis of the information provided in the strategic plans of the municipalities, it is possible to distinguish financial resources for their implementation. Municipal finances include the money from the municipality budget, special object-oriented subsidy from the State budget and Environmental Protection Support Programme, income from the provided services, finances of municipal budget, municipal privatization fund, finances from the EU Structural Funds, foreign funds, state budget, Road Maintenance and Development Programme, borrowed finances, money from private investors, and other sources.

Despite of many resources, Lithuania, as many other countries worldwide, still lacks finances because the demand for investments into the development of public infrastructure and services as well as improvement of their quality is growing. International experience shows that one of the means to receive additional financing is to establish public and private sector partnership, creating conditions for attracting private capital invest- 
ment to satisfy the needs of the public sector. The Law on Investment of the Republic of Lithuania defines such partnership as the means of cooperation of a state or municipal institution and private entity determined by legislation whereby the state or municipal institution transfers the activity of its functions to a private entity, and the private entity invests into the activity and property necessary for its execution, for which the entity receives payment determinate by legislation (Central Project Management Agency 2010).

Currently, the most municipalities do not track some categories of data on their RE at the municipal level. As a result, the expenses and revenues assessment for $\mathrm{RE}$ management is complicated (Kaganova 2012). Total amount of costs for RE use, maintenance and similar economic activity are often not included into the estimates of municipal RE management, neither is such information provided in the Annual Activity Reports or other public reports of the relevant institutions. Not linking the owned RE to all maintenance and operation expenses may form a misleading impression suggesting that the property is a good free of charge. If the total value of the property and the resulting costs are not estimated, an adequate evaluation of alternative expenses of municipal $\mathrm{RE}$ is impossible. In other words, the value of $\mathrm{RE}$ is not taken as the value to be used for other priorities in the municipalities (Lithuanian Free Market Institute and Lithuanian Real Estate Development Association 2008).

\subsection{Strategy}

Effective management of RE portfolio requires formation of professional teams of RE management that would prepare RE management strategies. Irrespective of the selected organizational control model, professional RE portfolio management reduces the costs of management and fulfils strategic aims of the municipalities. The development of strategic plans for RE management must provide the broadening limits of liability of people responsible for RE management; shifting from conservative to innovative management taking into account that the property may not only require municipal finances, but may also bring benefits and generate income (Deloitte Real Estate Advisory 2011). Different municipalities apply different RE strategies, for example: in managing $\mathrm{RE}$, the city of Rotterdam pays a great deal of attention towards reducing $\mathrm{CO}_{2}$ emissions, which is currently an especially relevant issue worldwide. Rotterdam Cli- mate Initiative has been signed obliging to diminish the $\mathrm{CO}_{2}$ emissions in the city by $50 \%$ till 2025 . To reach this purpose the city carries out renovation of old buildings and municipal RE objects for public needs. Another field is the rapidly developing stream "New ways of working": its key idea is that employees can work from home and fulfil the tasks as effectively as in the office, whereby the employer can reduce the costs. Such phenomenal method of work is observed, analysed and applied by a growing number of Dutch municipalities and other public institutions. Reducing the office area necessary for the staff at the state and municipal institutions enables saving a substantial amount of finances by selling or leasing the vacant RE. In all cases of any level RE strategy has to correspond with the overall policy and strategy of the city region or country adequately.

The Lithuanian Strategic Planning System consists of interrelated documents of strategic planning, institutions responsible for the preparation, implementation, assessment and correction of the documents, and statutory order and due dates for strategic planning.

The principal long-term strategic planning documents for municipalities, as for other public administration institutions, include the following: Long-term Development Strategy of the State, Long-term Strategy of Economic Development, National Strategy for Sustainable Development, Comprehensive Plan of the Territory of the Republic of Lithuania, and other long-term strategic planning documents. The mid-term documents on the municipal level encompass such papers as the Lithuanian Strategy for the Use of EU Structural Assistance, documents on regional planning (Regional Territorial Plans, Problem Area Development Programmes, etc.), and municipal development plans (General Plan of Municipality and Strategic Development Plan of Municipality). Finally, Strategic Action Plans of Municipalities are considered short-term (Buteniene et al. 2008).

The analysis of the formation of municipal RE management strategies for Lithuania revealed several essential problematic cases. The first problem is the conception of strategic planning processes: for a long time the preparation of the General Strategic Plan, Strategic Development Plan and Strategic Action Plan, as well as that of the budget was considered separate processes by the Lithuanian municipalities. In other words, many of the strategic planning specialists at the Lithuanian municipalities lack the perception of the key differences among such plans. Meanwhile, 
the preparation and implementation of such documents should be taken as constituent parts of a single process.

Another problem is that the Lithuanian higher education institutions have begun preparing RE management specialists rather recently (Vilnius Gediminas Technical University since 1999). For this reason, the majority of municipal staff at the RE management departments represent the older generation, that is accountants, managers, etc. Hence, currently, only some Lithuanian municipalities (Druskininkai, Birstonas, etc.) employ qualified RE strategic planning specialists who have acquired the necessary expedience abroad or by managing their private businesses. The third problem in RE management arises due to the frequent changes in the municipal authorities, which leads to changes in priorities and interests, highlevel of corruption, lack of personal responsibility for the results, etc.

Yet another problem requiring attention is the lack of legislation which would directly oblige the Lithuanian municipalities to prepare strategic plans. The same applies to the specialized methodology for strategic planning. As strategic management is unique for each municipality, there is no specific strategic management system that would completely suit each of them. Moreover, municipalities are not obliged to prepare strategic development plans taking into account the principal national strategic documents. The only aspect that is assessed is the implementation of the already-prepared strategic plans, which is assigned to the Service of Interior Audit (Government of the Republic of Lithuania 2006).

For managing municipal RE effectively all the above-mentioned elements of the public RE system, closely interrelated and forming a continuous chain, are essential. In the development of RE strategic management model for the Lithuanian municipalities, the authors have united all the elements of the public RE management system, which enables the formation of RE portfolio, determination of the necessary financing, and foreseeing of sources for financing. IT systems were invoked to collect and process data, while all the necessary information is stored in an information database. Having united all the elements of the system into the whole, the municipal staff could easily implement strategic plans and effectively manage RE. Thus, the next Section of the paper presents the RE strategic management model for the Lithuanian municipalities.

\section{STRATEGIC MANAGEMENT MODEL FOR MUNICIPAL RE}

In order to use the property as the means for improving the quality of services provided for the society, the municipalities have to manage their $\mathrm{RE}$ by applying strategic management principles directed at achieving public benefit efficiency, rationality and public law. Having analysed the legal ground and practice of $\mathrm{RE}$ management in the Lithuanian municipalities, the most relevant $\mathrm{RE}$ management research trends, $\mathrm{RE}$ management models and strategies of foreign countries and their best practice, a $\mathrm{RE}$ strategic management model for the Lithuanian municipalities was developed by the authors of this paper (Fig. 4).

The municipal strategic plan is implemented by assigning the priority directions with planning stages. They are intended for determining the demand of $\mathrm{RE}$ for developing municipal strategic direction, carrying out technical and economic assessment of the existing object-oriented RE, assessing the financial flow analysis and forecast of the existing object-oriented $\mathrm{RE}$, performing the financial flow analysis and exploitation forecast of new object-oriented $\mathrm{RE}$, making decisions on strategic perspectives of object-oriented RE, distributing priority $\mathrm{RE}$ budget for object-oriented $\mathrm{RE}$, and searching for new sources of financing. The planning stage encompasses the level of service provision of separate priority directions and the process of $\mathrm{RE}$ management primarily aimed at meeting public expectations, legal requirements and providing services at the price affordable for consumers.

After analysing all priority development directions and assessing the need for RE, municipal $\mathrm{RE}$ strategic management plan is prepared and strategic changes in municipal $\mathrm{RE}$ are planned by dividing $\mathrm{RE}$ into three principal groups; in the first group, $\mathrm{RE}$ in use, it is essential to include the costs of property exploitation, maintenance, renewal and repair. Similarly, in case of RE in the second group, new $\mathrm{RE}$, the costs necessary for $\mathrm{RE}$ construction, reconstruction, acquisition under agreements, gift, and use of RE taken-over from the state have to be assessed. RE out of use, ascribed to the third group, is property to be sold, leased, transferred, privatised, or its purpose is changed for the execution of different activities.

Having clearly defined strategic changes in $\mathrm{RE}$, the budget finances are distributed and the search for other sources of financing is carried out. Further, alternatives of $\mathrm{RE}$ portfolio are discussed and 


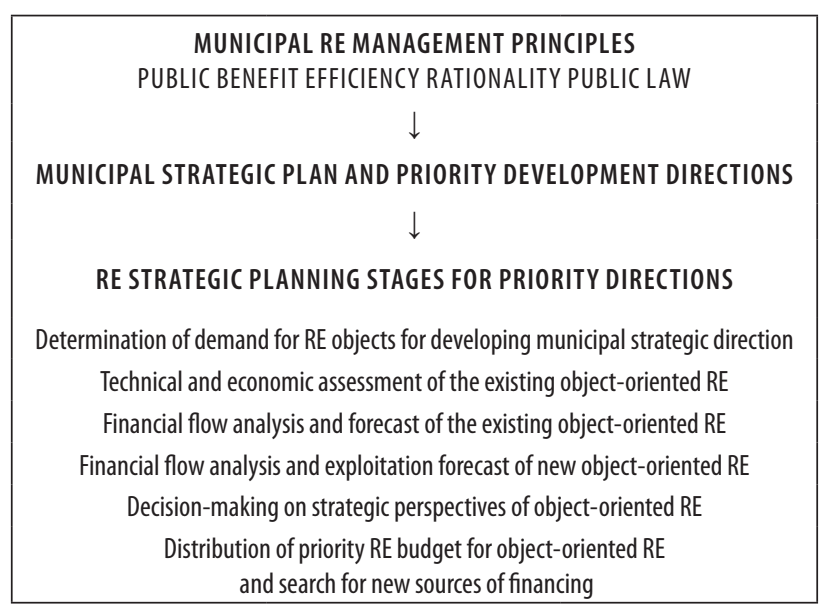

\begin{tabular}{|c|c|c|}
\hline \multicolumn{3}{|c|}{ STRATEGIC RE MANAGEMENT PLAN } \\
\hline \multicolumn{3}{|c|}{$\downarrow$} \\
\hline \multicolumn{3}{|c|}{ PLANNED STRATEGIC CHANGES OF MUNICIPAL RE } \\
\hline$\downarrow$ & $\downarrow$ & $\downarrow$ \\
\hline RE in use & New RE & RE out of use \\
\hline Exploitation & Construction & Sale \\
\hline and maintenance & Purchase & Lease \\
\hline Renewal & Taken-over from the state & Transfer \\
\hline Repair & Received as a gift & Privatization \\
\hline Support & Acquired under agreements & Refusal \\
\hline & Lease & Change of purpose \\
\hline \multicolumn{3}{|r|}{ 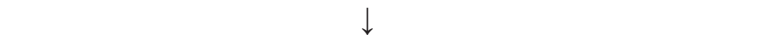 } \\
\hline \multicolumn{3}{|c|}{ BUDGET DISTRIBUTION AND SEARCH FOR SOURCES OF FINANCING } \\
\hline $\begin{array}{l}\text { Satisfaction of public } \\
\text { interests }\end{array}$ & $\begin{array}{l}\text { Public and private sector } \\
\text { partnership }\end{array}$ & $\begin{array}{l}\text { Optimization/rationality of } \\
\text { the use of RE financing }\end{array}$ \\
\hline$\downarrow$ & $\downarrow$ & $\downarrow$ \\
\hline \multicolumn{3}{|c|}{ ALTERNATIVES OF RE PORTFOLIO, THEIR ASSESSMENT AND OPTIMIZATION } \\
\hline \multicolumn{3}{|c|}{$\downarrow$} \\
\hline \multicolumn{3}{|c|}{ IMPLEMENTATION OF RE MANAGEMENT PROGRAMME } \\
\hline \multicolumn{3}{|c|}{$\downarrow$} \\
\hline \multicolumn{3}{|c|}{ MONITORING OF THE PROGRAMME AND FEEDBACK } \\
\hline
\end{tabular}

Fig. 4. Municipal RE strategic management model

an optimal portfolio is made up in order to ensure the satisfaction of public interests, partnership of public and private sector, as well as optimization of RE use. After all the stages have been completed, the programme is implemented, which, however, requires constant monitoring and continuous feedback.

Moreover, effective RE management requires $\mathrm{RE}$ information system which would be regularly updated by adding new information about $\mathrm{RE}$, identifying, classifying the property, determining its location, technical qualities, assessing its condition, i.e. by recording all facts on the life-cycle of a building or engineering structure. The information system must include accounting and financial data, data from $\mathrm{RE}$ register, description of technical maintenance of RE and its due dates, as well as comments and proposals for the use of $\mathrm{RE}$, and other information. The "road map" of required data would underpin the effective management of RE portfolios.

However, a well-prepared RE management information database is not enough for efficient property management. To reach the best results in $\mathrm{RE}$ strategic management, the process must be optimised. Since the Lithuanian municipalities have the GIS software installed, the staff has been trained to work on it, and currently a great deal of information is already stored in GIS databases, these systems are going to be applied for $\mathrm{RE}$ strategic management processes. For this reason, in the next stage of $\mathrm{RE}$ strategic management modelling, mathematical and artificial intelligence methods are going to be applied as the most suitable for solving RE strategic management related issues. Mathematical methods are planned to be used for assessing the condition of the property, forecasting its life-cycle, identifying priorities and optimising resources. Due to the dynamic nature of $\mathrm{RE}$ management process, artificial intelligence methods are a powerful tool enabling regular update of information which can be adapted.

\section{CONCLUSIONS}

Relevant research studies on municipal RE management cover many various issues related to the principles of territorial planning and their impact for RE development, environmental protection asset management, engineering infrastructure facilities management and development, IT application for RE management and RE management efficiency analysis and its assessment methods.

$\mathrm{RE}$ strategic management model for the Lithuanian municipalities has been developed based on the existing legal system and in accordance with RE management system components, such as strategy, organization, system, financing, and formation of $\mathrm{RE}$ portfolio. $\mathrm{RE}$ portfolio assets are allocated for the services provided by municipalities as well as $\mathrm{RE}$ management functions are assigned to the different municipal management level. The municipal-owned RE operation and maintenance framework is presented in the paper.

General principles of public benefit efficiency, rationality and public law lay as vital background for the main aim of efficient municipal RE management - life quality improvement for the inhabitants of the municipality. Municipal RE strategic management plan stage by stage is oriented to the priorities of strategic economic and social development tendencies of the region. $\mathrm{RE}$ portfolio is di- 
vided into three main groups: $\mathrm{RE}$ in use, the newly acquired RE and RE out of use. This classification allows adequate assessment of the existing municipal $\mathrm{RE}$ portfolio and development of new rational alternatives. A clearly established strategic RE portfolio and management changes would ensure the satisfaction of public interests, ensure the appropriate financing sources, and encourage publicprivate partnerships.

The developed model would enable the optimization of the municipal RE administration system, and saving of finances by planning an integrated purchase of services for RE management (cleaning, security, maintenance of buildings), decoration and exploitation - furthermore, it would facilitate the assessment of alternative uses of RE and estimate the expenses for their implementation before redistributing, transferring, selling or renovating the state property.

Aiming at more effective RE management, a reasonable estimation of the possibilities for municipalities to make free use of unexploited RE, which does not suit the needs of municipal RE managers for executing municipal functions, could be achieved. As a result, this would reduce the costs of $\mathrm{RE}$ management, and accelerate the introduction of a decent municipal $\mathrm{RE}$ financing system. The municipalities would then be forced to calculate not only the costs of RE acquisition and renewal, but also its exploitation.

When the model is implemented and the municipalities collect data on their RE, it is quite easy to develop a public municipal $\mathrm{RE}$ sales system using information systems. Similarly, the use of municipal RE management control system would enable the monitoring, coordination and control of managers' decisions on RE management, use and disposal. Having implemented the mentioned, it would become possible to apply measures of impact (legal and financial) for municipalities that refrain from any actions towards reasonable management of municipal RE.

The developed RE strategic management model was presented to the responsible staff in the Association of Local Authorities in Lithuania where it received a positive evaluation as being suitable for the efficient use in Lithuanian municipalities for municipal-owned RE management strategic plan preparation as well as implementation of strategic changes in municipal RE portfolio and management practice. Thus, in the next stage of modelling and optimization of $\mathrm{RE}$ strategic management process, mathematical and artificial intelligence methods are going to be applied.

\section{REFERENCES}

Abrate, G.; Erbetta, F.; Fraquelli, G.; Vannoni, D. 2011. The costs of disposal and recycling: an application to Italian municipal solid waste services, Carlo Alberto Notebooks, Working paper No. 232.

Anghinolfi, D.; Paolucci, M.; Robba, M.; Taramasso, A. C. 2013. A dynamic optimization model for solid waste recycling, Waste Management 33(2): 287-296. http:// dx.doi.org/10.1016/j.wasman.2012.10.006

Association of Local Authorities in Lithuania. 2012. Vietos savivaldos raida Lietuvoje [Local government in Lithuania] [online]. Lietuvos savivaldybiu portalas. Available at: http://www.lsa.lt/en/

Boamah, N. A.; Gyimah, C.; Nelson, J. K. B. 2012. Challenges to the enforcement of development controls in the Wa municipality, Habitat International 36(1): 136-142. http://dx.doi.org/10.1016/j.habitatint.2011.06.010

Buteniene, I.; Steponaviciene, I.; Kalvaitis, R. 2008. Strateginiu planu rengimo savivaldybèse tobulinimo rekomendacijos [Recomendations of strategic plan preparation accomplishment for municipalities]. Vilnius: LR Vidaus reikalu ministerija.

Central Project Management Agency. 2010. Administraciniu gebejimu stiprinimas ir viešojo administravimo efektyvumo didinimas. Igyvendinimo priemonès Nr. VP1-4.1.-VRM-06-V, Viešojo ir privataus sektoriu partneryste [Administrative capacity and efficiency of public administration. Implementing measures Nr. VP1-4.1.-VRM-06-V, Public Private partnership] [online] Available at: http://www. ppplietuva.lt/ [accessed 22 June 2012]

Deloitte Real Estate Advisory. 2011. Municipal real estate. Comparing public real estate management in European cities, Deloitte The Netherlands.

Ghapanchi, A. H.; Tavana, M.; Khakbaz, M. H.; Low, G. 2012. Methodology for selecting portfolios of projects with interactions and under uncertainty, International Journal of Project Management 30(7): 791803. http://dx.doi.org/10.1016/j.ijproman.2012.01.012

Government of the Republic of Lithuania. 2006. Lietuvos Respublikos viešojo administravimo istatymas [Republic of Lithuania Law on Public Administration], Valstybès žinios, 2006, Nr. 77-2975.

Government of the Republic of Lithuania. 2009. Centralizuoto valstybės turto valdymo 2009-2016 metu strategija [Centralized state property management strategy for 2009-2016], Valstybès žinios, 2009, Nr. 146-6492.

Halfawy, M. R. 2008. Integration of municipal infrastructure asset management processes: challenges and solutions, Journal of Computing in Civil Engineering 22(3): 216-229. http://dx.doi.org/10.1061/ (ASCE)0887-3801(2008)22:3(216)

Halfawy, M. R. 2010. Municipal information models and federated software architecture for implementing integrated infrastructure management environments, Automation in Construction 19(4): 433-446. http:// dx.doi.org/10.1016/j.autcon.2009.11.013

Huang, F. L.; Wang, F. 2005. A system for early-warning and forecasting of real estate development, Auto- 
mation in Construction 14(3): 333-342. http://dx.doi. org/10.1016/j.autcon.2004.08.015

Jacobs, H. M. 2012. Talking about property rights over tea: discourse and policy in the US and Europe, in Hartmann, T.; Needham, B. (Eds.). Planning by law and property rights reconsidered. Burlington: Ashgate Publishing Company, 71-96.

Kaganova, O. 2010. Government property assets in the wake of the dual crisis in public finance and real estate: an opportunity to do better going forward? Real Estate Issues 35(3): 31-41.

Kaganova, O. 2012. Guidebook on real property asset management for local governments. Washington, D.C.: Urban Institute.

Kaganova, O.; Akmatov, A.; Undeland, C. 2008. Introducing more transparent and efficient land management in post-socialist cities: lessons from Kyrgyzstan, International Journal of Strategic Property Management 12(3): 161-181. http://dx.doi.org/10.3846/1648715X.2008.12.161-181

Kaganova, O.; Nayyar-Stone, R. 2000. Municipal real property asset management: an overview of world experience, trends and financial implications, Journal of Real Estate Portfolio Management 6(4): 307-326.

Lepkova, N.; Vilutiene, T. 2008. Pastatu ūkio valdymas: teorija ir praktika [Facilities management: theory and practice]. Vilnius: Technika.

Ministry of Environment of the Republic of Lithuania. 2003. STR 1.01.09:2003 Statiniu klasifikavimas pagal jų naudojimo paskirti [Classification of buildings according to the purpose of their use], Valstybes žinios, 2003, Nr. 58-2611.

Lithuanian Free Market Institute and Lithuanian Real Estate Development Association. 2008. Effective state and municipal asset management. Lithuanian Free Market Institute and Lithuanian Real Estate Development Association.

Lumbers, J.; Conway, T.; Fynn, T.; Heywood, G. 2010. Optimal asset management planning: advances in water mains and sewers analysis within a new modelling environment, Water Asset Management International 6(3): 10-13.

National Audit Office. 2004. Improving procurement. Progress by the Office of Government Commerce in improving departments' capability to procure costeffectively, Report by the comptroller and auditor general. London: The Stationery Office.

Okot-Okumu, J.; Nyenje, R. 2011. Municipal solid waste management under decentralisation in Uganda, Habitat International 35(4): 537-543. http://dx.doi. org/10.1016/j.habitatint.2011.03.003

Peti, M. 2012. A territorial understanding of sustainability in public development, Environmental Impact Assessment Review 32(1): 61-73. http://dx.doi. org/10.1016/j.eiar.2011.03.004
Phelps, A. 2010. Rationale, practice and outcomes in municipal property asset management, Journal of Corporate Real Estate 12(3): 157-174. http://dx.doi. org/10.1108/14630011011074768

Phelps, A. 2011. Municipal property asset management - a comparative study of UK and Russia, International Journal or Strategic Property Management 15(4): 416-437. http://dx.doi.org/10.3846/1648 715X.2011.642537

Pijanowski, B. C.; Brown, G. D.; Shellito, B. A.; Manik, G. A. 2002. Using neural networks and GIS to forecast land use changes: a land transformation model, Computers, Environment and Urban systems 26(6): 553-575. http://dx.doi.org/10.1016/S01989715(01)00015-1

Sun, Y.; Huang, R.; Chen, D.; Li, H. 2008. Fuzzy setbased risk evaluation model for real estate projects, Tsinghua Science \& Technology 13(1): 158-164. http://dx.doi.org/10.1016/S1007-0214(08)70143-3

Venigalla, M. M.; Baik, B. H. 2007. GIS-based engineering management service functions: taking GIS beyond mapping for municipal governments, Journal of Computing in Civil Engineering 21(5): 331-342. http://dx.doi.org/10.1061/(ASCE)08873801(2007)21:5(331)

Vidanaarachchi, C. K.; Yuen, S. T. S.; Pilapitiya, S. 2006. Municipal solid waste management in the southern province of Sri Lanka: problems, issues and challenges, Waste Management 26(8): 920-930. http://dx.doi. org/10.1016/j.wasman.2005.09.013

Wang, T. K.; Sinha, S. K. 2004. Integrated system aproach for municipal pipeline asset management, North Americal Society for Trenchless Technology, Technical papers, 1-11.

Yard, S. 2004. Costing fixed assets in Swedish municipalities: effects of changing calculation methods, International Journal of Production Economics 87(1): 1-15. http://dx.doi.org/10.1016/S0925-5273(03)00025-2

Zavadskas, E. K.; Kaklauskas, A.; Banaitis, A. 2010. Application of e-technologies for regional development: the case of Vilnius city, Journal of Business Economics and Management 11(3): 415-427. http:// dx.doi.org/10.3846/jbem.2010.20

Zotos, G.; Karagiannidis, A.; Zampetoglou, S.; Malamakis, A.; Antonopoulos, I. S.; Kontogianni, S.; Tchobanoglous, G. 2009. Developing a holistic strategy for integrated waste management within municipal planning: challenges, policies, solutions and perspectives for Hellenic municipalities in the zero-waste, low-cost direction, Waste Management 29(5): 16861692. http://dx.doi.org/10.1016/j.wasman.2008.11.016

Zukauskas, V. 2011. Lietuvos savivaldybiu indeksas 2011 [Lithuanian municipalities Index 2011], [online] Lietuvos laisvosios rinkos institutas. Available at: http://files.lrinka.lt/analitiniai\%20darbai/Lietuvos_savivaldybiu_indeksas_2011.pdf [accessed 22 June 2012]. 